\title{
Innovative Approach in Teaching Graph Theory
}

\author{
Carmee Lyn B. Paylangco \\ University of Southern Mindanao Kidapawan City Campus \\ College of Education, Arts and Sciences \\ Brgy. Sudapin, Kidapawan City, Philippines
}

\begin{abstract}
Learners tend to get bored in learning Graph Theory and this results them getting low performance. Thus, this study was conducted to find empirical evidence on the attempt of having an innovative approach in teaching graph theory through the utilization of games to college students. This study was a pre experimental research in which pretest-post test was used. Moreover, it also utilized a qualitative research method to find out learners' feedback on the approach. The learners have their permanent group assignment and games were utilized for every topic. Pretest and post test were administered. The test scores were recorded, tabulated, analyzed and interpreted. Data were analyzed using paired-sample t-test. Results revealed a highly significant difference from pretest to post test of the students. Additionally, students give positive feedback on the attempt of this innovative approach in teaching graph theory. Such that, the following are some of their response: "I am excited to study graph theory because of games", "I look forward to games every meeting", etc. Therefore, college students exposed to games while learning shows very high knowledge in Graph Theory.
\end{abstract}

Keywords: Graph Theory; Mathematics; Teaching Approach; Innovative Approach; Game Theory; College; Philippines

\section{Introduction}

Graph theory is a relatively new area in mathematics that is only included in mathematics programs. Mathematics teaching in higher education has long embraced traditional methods: teacher-centered. Learners tend to get bored and this results them low performance in the subject. It is an overwhelming task for the teacher to make the class interesting enough for the students to actively participate in it. Finding an innovative way to teach the subject is a crucial skill for the teachers (Erickson, 1985).

Educators have to understand that students are most likely found to struggle with their major subjects such as graph theory. This leads to low retention level and grades, eventually leading to phobia or anxiety among learners. Traditional method with the use of blackboard, notebooks, and instructional learning do not fully address the needs of a class of diversed students. The teacher needs to develop a teaching approach that will engage the learners to participate, hence, giving them the chance to have experiential learning. This pedagogical approach will help students to learn through activities and perform simulations to discover concepts. (Cox, 2007)

There are already various attempts done to develop innovative approach in teaching. Rothore (2016) suggests transforming the subject into a game and assigning different activities to the students. Gamification of the subject can prove very helpful. Balneg (2013) shown the positive effect of the use of games in teaching mathematics.

Thus, this study was conducted to find empirical evidence on the use of innovative approach in teaching graph theory through the utilization of games to college students. 


\section{Methodology}

This study was a pre - experimental research in which pretest-post test was utilized. The subject of the study was the $3^{\text {rd }}$ year Bachelor of Secondary Education - Mathematics Major enrolled in graph theory at the University of Southern Mindanao Kidapawan City Campus, Sudapin Kidapawan City, Philippines.

Prior to the conduct of the experiment, a pretest was administered. It is composed of a 50-item multiple choice examination that had undergone test of validity and with a reliability level of .87 .

The students have their permanent group as assigned by the teacher-researcher. The result of their pretest scores were the basis for the group assignment. Games were utilized for every topic. For each topic to commence, the students perform an activity which leads to discovering the concept to be discussed. The teacher then gives guide questions and manages to have smooth transition towards the discussion of the lesson. Only 15 minutes was allotted for the lecture period. Afterwards, the students will play a game; this serves as an assessment method for the teacher as well to know whether students already had learned. Finally, quizzes were given which was done individually by the students.

Post test was administered. The material used was a 50-item multiple choice exam that has the same level of difficulty as the pretest. This has also undergone test of validity and reliability.

The test scores of all the tests were recorded, tabulated, analyzed and interpreted. Data were analyzed using weighted mean and paired-sample t-test.

Moreover, it also utilized a qualitative research method to find out learners' feedback on the approach. An intense observation was done, followed by deliberate and long-term reflection on what was observed. Questions regarding the observer's point of view and personal values were considered. Attitudes toward teaching and learning as well as measures of effectiveness are also examined.

\section{Results and Discussion}

\section{Pretest and Post test Scores of the Respondents}

Figure 1 shows the box plot of the pretest and post test scores of the respondents. During the pretest, the median score obtained by the respondents is 11 . This shows the prior knowledge of the respondents; however, the element of guessing cannot be neglected. Moreover, it is visually observed that there is a huge increase of the scores. The post test median becomes 37.5.

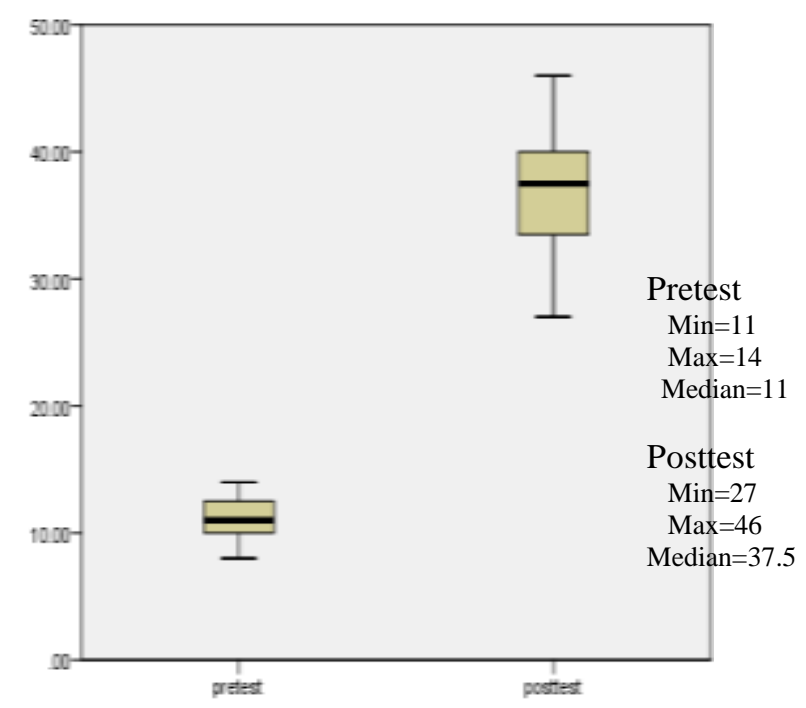

Fig. 1. Box Plot of the Pretest and Posttest Scores of the Respondents. 
Table 1 shows that the students have low prior knowledge Graph Theory with a pretest mean score of only 11.1250. But on the post test scores, students showed very high knowledge with the post test mean score of 36.9167. The t-computed is -33.564 and the p-value of $0.000<0.01$ reveals that students obtained highly significant increase in their scores from pretest to post test.

Table. 1. Test of Difference in the Pretest and Posttest Scores of the Respondents.

\begin{tabular}{|c|c|c|c|c|}
\hline Exam & Mean & $\begin{array}{c}\text { Mean } \\
\text { Difference }\end{array}$ & $\mathrm{t}$ & $\mathrm{p}$-value \\
\hline Pretest & 11.1250 & 25.7917 & - & 0.000 \\
Posttest & 36.9167 & & $33.564^{* *}$ & \\
& & & & \\
\hline \multicolumn{5}{|c}{$*$ - highly significant difference }
\end{tabular}

Figure 2 shows the scatter plot of the pretest and posttest scores. Visually, we can interpret that there is a positive relationship among variables.

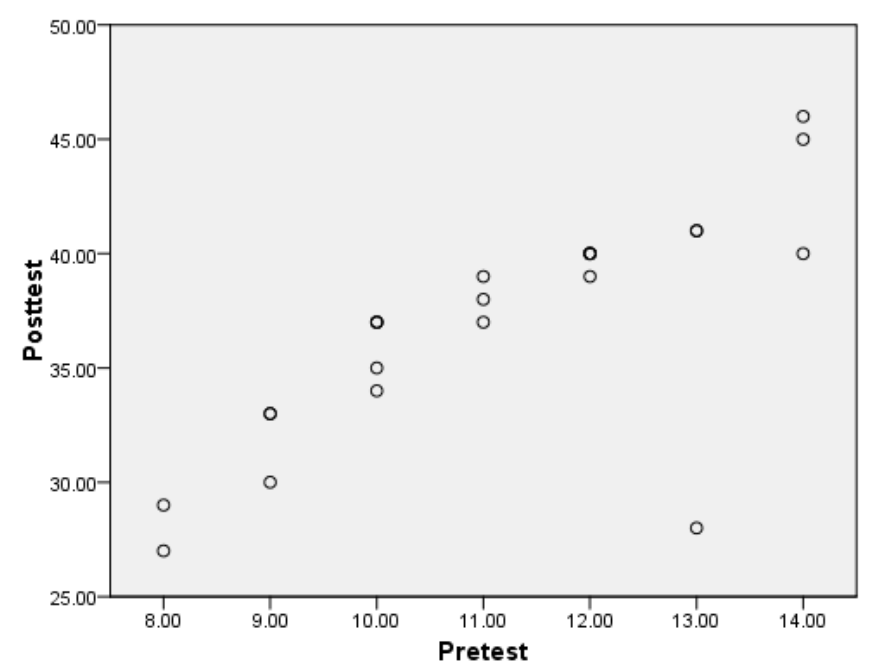

Fig. 2. Scatter plot of the Pretest and Posttest Scores.

Table 2 shows the test of relationship between the pretest and posttest scores of the respondents. The $r$ computed $=.762$ reveals a moderately strong positive relationship between the scores. It implies that the students who scored high in the pretest also scored high in the posttest. It further implies the consistency of the students' performance.

Table 2. Test of Relationship between the Pretest and Posttest Scores of the Respondents.

\begin{tabular}{|l|c|c|c|}
\hline \multicolumn{1}{|c|}{ Exams } & $\mathrm{r}$ & $\begin{array}{c}\text { Degree of } \\
\text { relationship }\end{array}$ & $\mathrm{p}$-value \\
\cline { 1 - 4 } Pretest & $.762 * *$ & $\begin{array}{c}\text { Moderately } \\
\text { strong }\end{array}$ & 0.000 \\
\cline { 1 - 1 } Posttest & $* *$-highly significant relationship \\
\hline
\end{tabular}

Students' Feedback on the Teaching Approach Used.

Table 3 shows the transcribed feedback of the students regarding the innovative approach in teaching Graph Theory.

Table 3. Feedback of the students on the Teaching Approach Used. 


\begin{tabular}{|c|c|}
\hline Questions & Students' Response \\
\hline $\begin{array}{l}\text { Give a } \\
\text { summary of } \\
\text { your experience } \\
\text { in Graph } \\
\text { Theory. }\end{array}$ & $\begin{array}{l}\text { 1) I perform well in the subject. } \\
\text { 2) I enjoy the games given by the instructor. } \\
\text { 3) I look forward to the activities in the class. I get to interact with my peers } \\
\text { and it helped me to develop my critical thinking skills. } \\
\text { 4) I become more independent and confident in learning concepts of graph } \\
\text { theory. } \\
\text { 5) Learning by experience and enjoyment thru games make me love the } \\
\text { subject more. }\end{array}$ \\
\hline $\begin{array}{l}\text { How do you } \\
\text { find the } \\
\text { teaching } \\
\text { approach used? }\end{array}$ & $\begin{array}{l}\text { 1) I find the activity interesting. } \\
\text { 2) It helps me to fully understand the concepts in Graph Theory. } \\
\text { 3) It is learner-centered. } \\
\text { 4) It requires higher order thinking skills. } \\
\text { 5) It promotes higher retention to us students because we are part of the } \\
\text { discussion and we discover the concepts by the creative questioning of our } \\
\text { instructor. }\end{array}$ \\
\hline $\begin{array}{l}\text { Points to } \\
\text { Consider }\end{array}$ & $\begin{array}{l}\text { 1) Some of the activities are difficult. } \\
\text { 2) I was shocked with the approach used because I was used to be taught with } \\
\text { lecture method. } \\
\text { 3) It makes the subject a lot more difficult for me. }\end{array}$ \\
\hline
\end{tabular}

\section{Conclusion}

This research study concludes that college students exposed to games while learning shows very high knowledge in Graph Theory. Moreover, students displayed positive attitude towards the approach used. This is manifested by their good feedback during the focused grouped discussion and in depth interview conducted. Therefore, it is recommended to consider applying games in teaching Graph Theory.

\section{Acknowledgement}

The researcher acknowledges the following individuals who helped in the conduct of this study: Dr. Ronielyn F. Pinsoy, Dr. Crisina Q. Dela Cruz, Dr. Vhenus Maglinte, Engr. Carlito Balneg, Mrs. Salome Balneg, Mr. Leonardo Paylangco Jr., Ms. Jeconi Joice Tanggan, Mr. Dennis Dimalidseg and Mr. Michael Fausto Tacdoro. Moreover, the researcher also acknowledges the Mathematics Enthusiasts' Society and the BSE-3 Math majors of USM-KCC who served as the respondents of the study.

\section{References}

1. C. Balneg. 2013. Structured Puzzles and Games on Students' Achievement in Plane Trigonometry. USMKCC Research Journal. 
2. F. Erickson. 1985. Qualitative Methods in Research on Teaching Occasional Paper. https://www.researchgate.net/publication/234580570_Qualitative_Methods_in_Research_on_Teachi ng_Occasional_Paper_No_81

3. R.V. Naidu,. 2006. Teacher's Behaviour \& Student's Learning, Neelkamaal Publications Pvt. Ltd.. https://www.sapnaonline.com/books/teachers-behavior-students-leaming-study-rv-naidu-8183161049-9788183161046

4. Rothore, M. 2016. Relationship between Wisdom and Coping among College Students. https://thekeep.eiu.edu/cgi/viewcontent.cgi?article=3509\&context=theses

5. Cox, W. 2007. Practical, Theory Based Principles for Teaching Mathematics in Higher Education. http:/homepages.warwick.ac.uk/ masbm/MVME/cox.pdf 